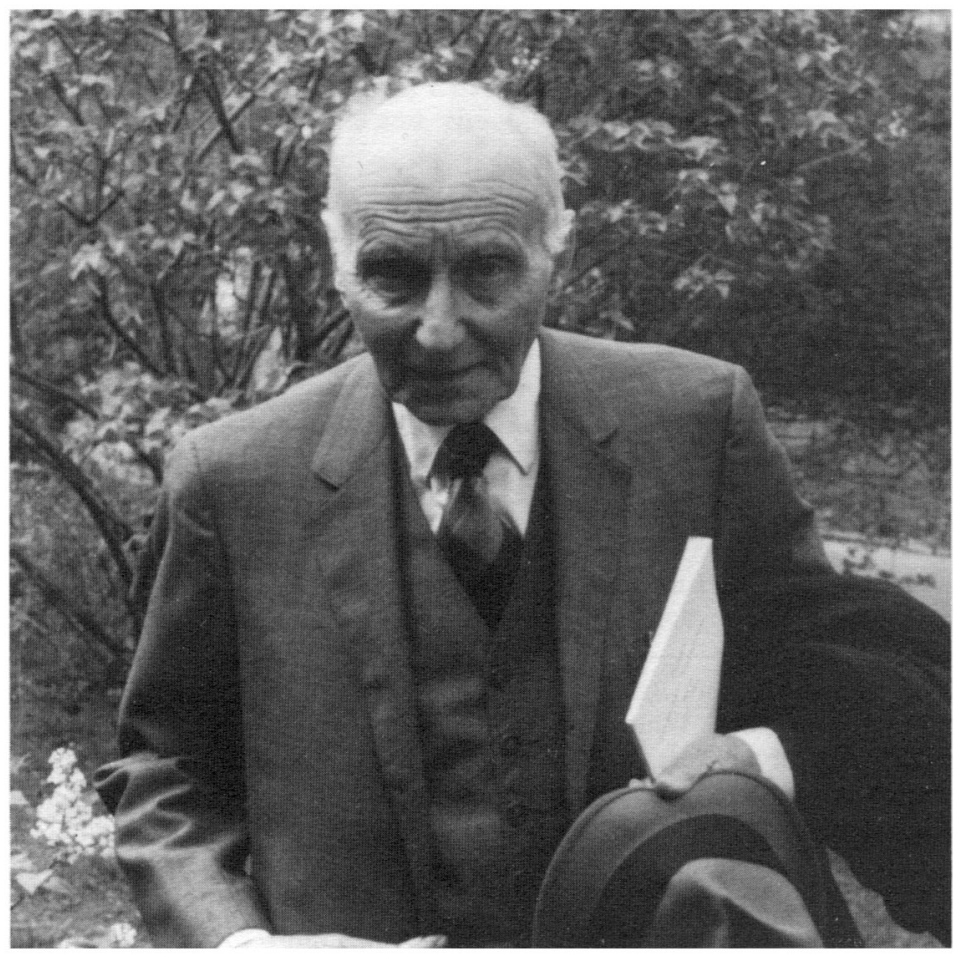




\title{
Fritz Leonhard Redlich
}

\author{
1892-1978
}

Fritz Reduich's emigration in 1936 from Hitler's Germany to the United States was to divide his life into two parts of almost equal length. On the surface, his break with the past was a complete one. He never saw his native country again. Inwardly, however, he continued to carry with him the indelible imprints of his formative years. To his American friends he remained unmistakably German: a typical German professor. But Fritz Redlich had never been a German professor.

When he was born, halfway between the foundation of the Kaiserreich and the outbreak of World War I, Germany was just beginning to look at herself as a budding world power. Redlich grew up in Berlin where his father ran a prospering textile business. It seemed a foregone conclusion that the only son should one day take over the firm. If Redlich could have chosen freely he would probably have studied art history and perhaps also social and economic history. He had read Max Weber, Ernst Troeltsch, and Werner Sombart and he attended their lectures at the university. But to please his parents he first studied chemistry, passed an examination, and only thereafter turned to economics. In those years, economics in Germany was still dominated by the Historical School. The Berlin chair was held by Gustav von Schmoller, an impressive teacher who, in Redlich's own words, ${ }^{1}$ tried to integrate the economic discipline within the broader framework of a social science governed by ethical norms. In the summer of 1914, only 22 years old, Redlich took his doctor's degree under the guidance of Ignaz Jastrow with a thesis about the economic significance of the German coal-tar dyes industry.

When the war broke out Redlich was not enthusiastic, but out of acquired patriotism he volunteered like everyone else. For four years the young cavalry officer led a machine-gun company into

Business History Review, Vol. LIII, No. 2 (Summer, 1979). Copyright (C) The President and Fellows of Harvard College.

1 Michael Stürmer, "Historiker in der Emigration: Fritz Redlich" (unpubl. manuscript of an interview conducted with Dr. Redlich in 1977). Dr. Redlich suggested before his death that appropriate excerpts from this interview be translated and quoted in this memorial article. 
numerous battles. His main concern was not to expose his men to any unnecessary danger and thus to save as many lives as possible.

The revolution of 1918 put an end to an era with which he had never fully identified himself. The new republic did not appeal to his sense of tradition, but he was ready to defend it (as a volunteer in one of the many "free corps" of those days) against the political extremism of rightist and leftist radicals. He joined Gustav Stresemann's Deutsche Volkspartei, a party composed of conservative and progressive elements, and became a "rational republican."

He now worked full-time in the family firm without taking much interest in its transactions. Looking back at this period he later called his decision to go into business "a sin against the spirit," which had prevented him from devoting his best years to scholarly work. When the firm failed in the Great Depression Redlich seems to have considered it a last chance rather than a catastrophe. But first he had to look for a job. He accepted an attractive offer by the German Agricultural Association to organize its fur trade department. Working conditions were liberal, leaving plenty of time for his private research. For years Redlich had been cherishing the idea of writing a history of German business leaders. He now began to prepare his "Habilitation," which would have opened to him a university career. A first attempt was stopped by a member of the Berlin faculty, unsympathetic to the "outsider," who felt that business history was not a suitable subject. To prepare a second try Redlich turned to the history of advertising.

Hitler's coming to power in 1933 chilled the political and cultural climate in Germany like a sudden freeze. Redlich was appalled by the smoothness with which the "Gleichschaltung" seemed to function in all areas and even more by the tacit consent of those who were brought into line. The universities were easily seized by the Nazis, and any further attempt by Redlich to pursue his academic goals would have necessitated the submission to a primitive and brutal philosophy that he utterly abhorred. On March 27, 1936, Redlich left Germany knowing it would be a farewell forever. When he arrived in New York no relatives or friends awaited him, he was almost penniless, and he spoke very little English.

He tried to establish contacts with American universities, but his credentials were not very impressive. His book on the history and theory of advertising had been published in 1935, but he was without "Habilitation," had no teaching experience and was almost 
45 years old. Schumpeter and Taussig, whom he visited at Harvard, were not in a position to offer much assistance, but Schumpeter encouraged him to continue his studies in business history. Redlich was finally able to secure his livelihood by accepting teaching jobs at small colleges, first in Michigan and later in Georgia, but he continued to experience difficulties in adapting himself to his new environment and at times seems to have led a very lonely life. He later recalled that often he did not speak a single word between Friday afternoon and Monday morning. Only once a year could he afford to spend some time at Harvard in order to work in its libraries and to meet people who shared his interests. In 1940, he was one of the founding members of the Economic History Association, and in the same year he published the first volume of a planned history of American business leaders.

His material situation improved in 1943 when he received the post of economic analyst with the Federal Public Housing Authority. From 1948 to 1950 he was director of research and statistics for the State Housing Board of Massachusetts, a job that made it possible for Redlich to take up permanent residence in close vicinity to Harvard and to pursue his research more effectively. For several years he had been working on a history of American banking from its beginnings to the creation of the Federal Reserve System. The two volumes of The Molding of American Banking, Men and Ideas appeared in 1947 and 1951 and were reprinted in 1968. This monumental work, in which Redlich tried to instill elements of the German tradition of "Persönlichkeitsgeschichte" into American institutional history and which Stuart Bruchey later called "the finest study of the history of banking in the U.S. that we possess," seems to have been written in almost total isolation. "There are few to whom the author must express his gratitude for assistance during the time he was working on the book," Redlich wrote in the preface. Among those who offered help and advice in this critical period, when Redlich was working feverishly on what he must have considered his last opportunity to establish himself as a respected scholar, Arthur $\mathrm{H}$. Cole was by far the most important.

It was Cole who in 1950 invited Redlich to become a Senior Associate at the Research Center in Entrepreneurial History, which had brought together at Harvard a group of scholars and students interested in business history and which, until its termination in 1958 , served as a starting basis for a variety of research projects. The Center took special interest in investigating also less-well- 
known types of business leadership, a policy that coincided with Redlich's own intentions. In 1954 he began to concern himself with the history of military entrepreneurship in Germany between 1350 and 1800 . Ten years later $(1964 / 65)$ he published the two volumes of his masterful study, The German Military Enterpriser and his Work Force. The work was hailed as a bold new approach to military history by means of an economic analysis of the chang. ing conditions of warfare since the late Middle Ages. It was noted with surprise that a book based on such extensive German source material could be written in America. Fritz Redlich was now recognized, also in his native country, as a social and economic historian of the first order and received honorary doctorates from the Universities of Erlangen (1960) and Berlin (1967). A selection of his essays on the history and theory of entrepreneurship was translated into German and reprinted as Der Unternehmer (1964). The book, which is dedicated to Arthur $\mathrm{H}$. Cole, reflects the breadth and diversity of Redlich's contributions. A second collection of papers was published in English in 1971 as Steeped in Two Cultures, and shows Redlich's intellectual development during 35 years in the United States. Both volumes contain only a small portion of the some 150 articles that came from his pen between 1929 and 1976.

When the Center was closed in 1958 Redlich continued to be closely associated with Harvard and particularly with the Business School. His advice was sought by many young scholars working on such diverse topics as banking history, general entrepreneurial history, and the intellectual history of modern Germany. At Harvard Redlich had become, since the early 1950s, a sort of "liaison officer" for two generations of visiting German historians, generously offering them invaluable practical services and discussing their projects with them in his modest home or in a quiet corner of the Kress Library. In such discussions he was always patient, sometimes almost fatherly, and his criticism was never sarcastic. The total unselfishness of his interest in others and their work and his imperturbable kindness were as impressive as his remarkable scholarly stature. In spite of his advancing age, Redlich continued to work hard, to publish on a wide range of subjects and to be a lively and stimulating partner in the discussions with his colleagues at the Business School. He still worked regularly in the stacks of Baker Library, and advised the curator of the Kress Collection on the acquisition of German books. His youthfulness, his humor, and 
the freshness and openness of his mind gave an appearance of timelessness to his personality.

Fritz Redlich was probably the most imaginative business historian of his time. ${ }^{2}$ Unlike Schumpeter, he did not create a new theory of the role of the entrepreneur in the process of economic development. His theoretical writings show, in fact, that he considered Schumpeter's concept too narrow to cover the entire range of significant entrepreneurial activities. ${ }^{3}$ Redlich preferred to look at the full "Gestalt" of the entrepreneur with the many-faceted eye of the genuine historian. His own versatility, which had been shaped by the heritage of the German "Historismus," made him suspicious of theoretical one-sidedness. Hence his reservations about the "Marshall School" of American economic history and about the New Economic History. ${ }^{4}$

Soon after his arrival in the United States, Redlich had become aware of the fact that his training as an economist, which he had received in Germany before 1914, was inadequate by modern standards and did not even supply him with the tools he would have needed to do quantitative work in economic history. The solution that he found to his problem was to try to accomplish a synthesis between the "understanding" and the analytical approach to historical questions. But in spite of his willingness to make concessions to his new environment, typology and not quantification remained his principal working method. His historical universe was not composed of statistical atoms but of human individuals, who could be grouped according to types and by means of analogies but not dissolved into masses of impersonal data. Redlich's lifelong interest in autobiographies can be explained by this basic orientation toward personalities and their roles as shapers of economic, social, and cultural developments.

In Redlich's later years, a tendency to revert to his intellectual origins became more and more obvious. "Is it not possible," he asked in a speech made on his eightieth birthday, "to devise a kind of economic theory which deals with economic phenomena as wholes, as entities, as Gestalt, without analyzing them to pieces?" 5 He cited Hegel: Die Wahrheit ist das Ganze (the truth

\footnotetext{
${ }^{2}$ See Walther Herrmann, "Fritz Redlich," Zeitschrift für Unternehmensgeschichte, XXIV (1979), 5-8.

${ }^{3}$ See Alfred D. Chandler, Jr. and Fritz Redlich, "Recent Developments in American Business Administration and their Conceptualization," Business History Review, XXXV (1961), 23.

4 See Fritz Redlich, "Potentialities and Pitfalls in Economic History," Explorations in Entrepreneurial History, Second Series, vol, 6 (1968), 93-108.

5 Fritz Redlich, "Work Left Undone," Harvard Library Bulletin, XXI (1973), 6.
} 
is the whole), and he recognized this leitmotif in the work of the three historians he most admired: Sombart, Schumpeter, and Max Weber. His interest in business history remained strong. He would speak with admiration of Alfred D. Chandler's structural approach to the history of the modern corporation; he kept himself informed about attempts in Germany and Austria to establish special business history associations; and he continued to be a member of the advisory board of the Business History Review. But of even greater concern to him now were more general themes like the interplay of material and spiritual forces in history, cultural linkages between epochs, historical generations, themes that he would have preferred to devote a greater part of his life and work to.

When Fritz Redlich's health began to decline and he realized that he would soon have to end his work, he gave away to friends what little he owned: his books, his papers, a pair of beautiful riding boots that he had last used as a young officer in 1918. The money that, by virtue of his incredibly modest life, he had been able to save over the years was designated by him for the acquisition of books by Harvard's Kress Library. Seriously ill since the spring of 1978, he spent the last months of his life in a nursing home, where his friends visited him almost daily. Dr. Redlich died on October 21, 1978, in Newton, Massachusetts, in his eightyseventh year. A memorial service was held in Appleton Chapel of Memorial Church, Harvard University, on November 22, 1978.

Hans Jaeger, UNIVERSITÄT MÜNCHEN 